\title{
Anti-PD-1/PD-L1 Blockade
} Immunotherapy Employed in Treating Hepatitis B Virus Infection-Related Advanced Hepatocellular Carcinoma: A Literature Review

\author{
Bin $\mathrm{Li}^{1+}$, Cong Yan ${ }^{1+}$, Jiamin Zhu ${ }^{1}$, Xiaobing Chen ${ }^{2}$, Qihan Fu ${ }^{1}$, Hangyu Zhang ${ }^{1}$, \\ Zhou Tong ${ }^{1}$, Lulu Liu ${ }^{1}$, Yi Zheng ${ }^{1}$, Peng Zhao ${ }^{1}$, Weiqin Jiang ${ }^{1 *}$ and Weijia Fang ${ }^{1 *}$ \\ ${ }^{1}$ Department of Medical Oncology, The First Affiliated Hospital, School of Medicine, Zhejiang University, Hangzhou, China, \\ ${ }^{2}$ Department of Oncology, Henan Cancer Hospital, The Affiliated Cancer Hospital of Zhengzhou University, Zhengzhou, China
}

\section{OPEN ACCESS}

Edited by:

Katy Rezvani,

University of Texas MD Anderson Cancer Center, United States

Reviewed by:

Tung-Hung Su,

National Taiwan University

Hospital, Taiwan

Catherine Sautes-Fridman, INSERM U1138 Centre de Recherche des Cordeliers, France

*Correspondence:

Weiqin Jiang

xixijwq80@163.com

Weijia Fang

weijiafang@zju.edu.cn

†These authors have contributed equally to this work

Specialty section:

This article was submitted to Cancer Immunity and Immunotherapy,

a section of the journal

Frontiers in Immunology

Received: 10 November 2019

Accepted: 29 April 2020

Published: 28 May 2020

Citation:

Li B, Yan C, Zhu J, Chen X, Fu Q

Zhang $H$, Tong Z, Liu L, Zheng Y,

Zhao P, Jiang $W$ and Fang $W$ (2020)

Anti-PD-1/PD-L1 Blockade

Immunotherapy Employed in Treating

Hepatitis B Virus Infection-Related Advanced Hepatocellular Carcinoma:

A Literature Review.

Front. Immunol. 11:1037.

doi: 10.3389/fimmu.2020.01037
Hepatitis B virus (HBV) infection is regarded as the main etiological risk factor in the process of hepatocellular carcinoma $(\mathrm{HCC})$, as it promotes an immunosuppressive microenvironment that is partially mediated by the programmed cell death protein 1 (PD-1)/programmed death-ligand 1 (PD-L1) signaling pathway. The tumor microenvironment (TME) of HBV-related HCC is indeed more immunosuppressive than microenvironments not associated with viruses. And compared to TME in hepatitis $\mathrm{C}$ virus $(\mathrm{HCV}$ ) infected $\mathrm{HCC}$, TME of HBV-related HCC is less vascularized and presents different immune components resulting in similar immunosuppression. However, few studies are focusing on the specific side effects and efficacy of PD-1/PD-L1 blockade immunotherapy in HBV-related HCC patients, as well as on the underlying mechanism. Herein, we reviewed the basic research focusing on potential TME alteration caused by HBV infection, especially in HCC patients. Moreover, we reviewed PD-1/PD-L1 blockade immunotherapy clinical trials to clarify the safety and efficacy of this newly developed treatment in the particular circumstances of HBV infection. We found that patients with HBV-related HCC displayed an acceptable safety profile similar to those of non-infected HCC patients. However, we could not determine the antiviral activity of PD-1/PD-L1 blockade because standard anti-viral therapies were conducted in all of the current clinical trials, which made it difficult to distinguish the potential influence of PD-1/PD-L1 blockade on HBV infection. Generally, the objective response rates (ORRs) of PD-1/PD-L1 blockade immunotherapy did not differ significantly between virus-positive and virus-negative patients, except that disease control rates (DCRs) were obviously lower in HBV-infected HCC patients.

Keywords: immunotherapy, hepatocellular carcinoma, hepatitis B virus, programmed cell death protein 1, programmed death-ligand 1 , tumor microenvironment

\section{BACKGROUND}

Liver cancer was predicted to be the sixth most commonly diagnosed cancer and the fourth-leading cause of cancer death in 2018, with about 841,000 new cases and 782,000 deaths annually (1). Among the various types of primary malignant hepatic tumors, hepatocellular carcinoma (HCC) is the most common, accounting for roughly $75-85 \%$ of cases $(1,2)$. 
Chronic hepatitis B virus (HBV) infection is always regarded as a primary risk factor for the development of HCC and accounts for at least $50 \%$ of HCC cases worldwide $(3,4)$. The world is of a high prevalence of $\mathrm{HBsAg}$, especially eastern Asian. At least 120 million Chinese people carry HBsAg which makes China a highly endemic area, and the second-greatest proportion of cancer deaths is attributable to HBV (5-7). Notably, the potential risk of developing HCC is dozens of times higher for chronic HBV carriers compared with the uninfected population (8).

Programmed cell death protein 1 (PD-1), an immunosuppressive molecule expressed in B cells, $\mathrm{T}$ cells, dendritic cells and natural killer (NK) $\mathrm{T}$ cells to suppress anticancer immunity, has been shown to be correlated with the course of HCC and with HBV infection (9-12). Nowadays, anti-PD-1/programmed death-ligand 1 (PD-L1) pathway blockade has become a promising and favorable immunotherapy for adjusting host immune responses and inhibiting the development of various types of tumors (13-17). However, HBV infection exerts complex biological effects on the tumor microenvironment (TME), which probably affects the efficacy of immunotherapy to a certain extent. Unless the safety and efficacy of anti-PD-1/PD-L1 therapy in HBV-infected HCC patients can be confirmed, the role that this immune-adjusted therapeutic strategy could play in $\mathrm{HBV}$ infection related $\mathrm{HCC}$ might not be clarified.

\section{HBV INFECTION RELATED LIVER IMMUNE MICROENVIRONMENT ALTERATION}

\section{Liver Tolerogenic Mechanisms: Natural Status}

In the human liver, normal biological processes involve a large amount of antigen exposure. The existence of antigens could lead to inactivation, tolerance, and apoptosis of $\mathrm{T}$ cells, protecting the liver from autoimmune damage of continuous immune stimulation (18). Previous studies have revealed several tolerogenic mechanisms, including a porous layer established to isolate hepatic tissue from the blood (19) and the release of the immunosuppressive cytokines interleukin 10 (IL-10) or transforming growth factor-beta (TGF- $\beta$ ) from liver dendritic cells, liver sinusoidal endothelial cells (LSECs), and Kupffer cells (20). Additionally, the liver could generate antigen-specific Cluster of Differentiation $4\left(\mathrm{CD}^{+}\right)$/forkhead box P3 (FOXP3 ${ }^{+}$) regulatory $\mathrm{T}$ cells (Tregs) (21) and downregulate the expression of B7-1/B7-2 on the surfaces of LSECs, which would limit the ability of antigen-presenting cells (APCs) to activate $\mathrm{CD} 4^{+} \mathrm{T}$ cells (22). The immune checkpoint pathways, B7-CD28/cytotoxic $\mathrm{T}$ lymphocyte-associated antigen-4 (CTLA-4) and PD-1/(PDL1, PD-L2), also contribute to natural liver immune tolerance $(19,23)$. Furthermore, both harmless and harmful antigens could protect the liver from autoimmune damage via inherent immune tolerance or escape mechanisms (22).

\section{HBV Infection-Based TME}

HCC is regarded as a highly heterogeneous disease of varying immune microenvironments between the tumor and adjacent tissues (24). Chronic inflammation is generally considered to be the ongoing expression of different cytokines and recruitment of immune cells to troubled regions (22). HBV virus infection induces immunosuppression, and then peripheral immune tolerance as the chronic infection progresses; finally, it mediates oncogenesis, due to impaired immune surveillance (25). In chronic viral hepatitis, immune inhibitory checkpoints, including PD-1/PD-L1, CTLA-4, and T-cell immunoglobulin and mucin domain-3 (TIM-3), play essential roles in immunosuppression by downregulating the responses of T cells (22).

Figure 1 illustrates the immune landscape for HBV-related TME in HCC. $\mathrm{CD}^{+} \mathrm{T}$ cells provide a vital antitumor response in the surrounding HCC microenvironment. The gradually increasing frequencies of circulating $\mathrm{CD}^{+} \mathrm{T}$ cells expressing $\mathrm{PD}-1$ were reported to be relevant to the progression of $\mathrm{HBV}$ related cirrhosis to HCC. Apoptosis of $\mathrm{CD}^{+} \mathrm{T}$ cells was also promoted by hepatoma cells via PD-L1 upregulation (26). Of note, transcriptional analysis has discovered an extra cytotoxic phenotype of $\mathrm{CD}^{+}$tumor-infiltrating lymphocytes in $\mathrm{HCC}$ patients with undetectable serum levels of HBV (27). In addition, HBV replication was also found to be associated with a higher proportion of HBV-specific CD8 ${ }^{+} \mathrm{T}$ cells. TIM-3 inhibits $\mathrm{Th}_{1}$ responses and expresses effective cytokines such as tumor necrosis factor (TNF) and interferon-gamma (INF- $\gamma)(27,28)$. A recent study revealed an inverse association between TIM-3 expression levels and clinical outcomes in HBV-infected HCC (29): The proportion of TIM- $3^{+} \mathrm{CD}^{+} \mathrm{T}$ cells in tumor tissues from $\mathrm{HBV}^{+}$patients was much higher than in those from $\mathrm{HBV}^{-}$patients $\left(\mathrm{CD}^{+}: 15 \%\right.$ vs. $2 \%$ ), and the TIM-3/galectin9 signaling pathway could mediate T-cell functional exhaustion in HBV-infected patients. Notably, higher expression of PD1 and lymphocyte-activation gene 3 (LAG3), as well as lower expression of CD28 and CD127, were commonly found in tumor-infiltrating $\mathrm{CD}^{+} \mathrm{T}$ cells of $\mathrm{HBV}$-related $\mathrm{HCC}$ patients (30-32).

In the TME, Tregs play an immunosuppressive role by producing cytokines, such as IL-10, IL-35, and TGF- $\beta$, and by inhibiting $\mathrm{Th}_{1}$ or $\mathrm{Th}_{2}$ cell activation (33). Frequencies of Tregs were higher in $\mathrm{HBV}^{+} \mathrm{HCC}$ than $\mathrm{HBV}^{-} \mathrm{HCC}$ patients. Decreased PD-1 expression and increased IL-10/TGF- $\beta$ secretion of $\mathrm{CD}^{+}{ }^{+} \mathrm{CD} 25^{+}$Tregs were found in $\mathrm{HBV}^{+} \mathrm{HCC}$ patients (34). However, researchers have also clarified that the increased PD1 expression in Tregs from $\mathrm{HBV}^{+}$patients indicated a more suppressive and exhausted immune condition (35). In the studies mentioned above, Tregs had different levels of PD-1 expression but resulted in similarly suppressive immune conditions in HBVbased TMEs. A next-generation sequencing (NGS) analysis (35) revealed that Tregs isolated from HBV-infected HCC had distinct transcriptomic signatures containing 289 differentially expressed genes. For instance, upregulated expression of FOXP3, and other genes involved in the IL-10 pathway including interleukin 1 receptor type 1 (IL1R1) and TNF receptor superfamily member 1B (TNFRSF1B) were found in Tregs from HBV-infected HCC. And $L A G 3$, essential for suppressive activity, was also enriched. CTLA-4 is another immunosuppressive molecule, and an in vitro experiment suggested that $\mathrm{CD} 4{ }^{+} \mathrm{CD} 25^{+}$Tregs isolated from peripheral-blood mononuclear cells could upregulate the 

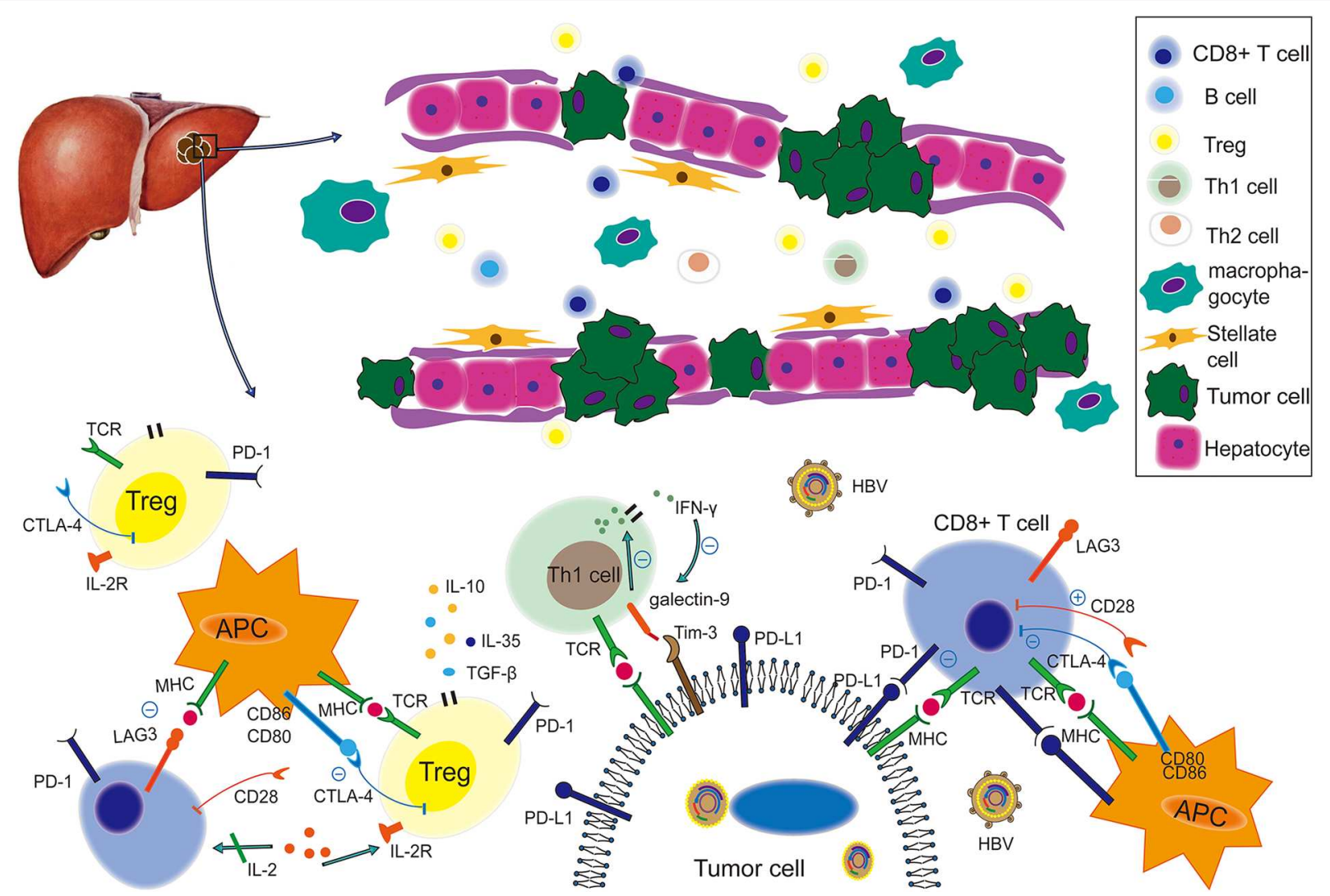

FIGURE 1 | The immune landscape of the HBV-based tumor microenvironment. Under virus infection conditions, the immune status of an HCC-bearing host becomes more immunosuppressive and is characterized by weakening of co-stimulatory signal, enhancement of co-inhibitory signals, functional impairment, decreased quantity of tumor-killing T cells, such as CD8 ${ }^{+}$and enrichment of Tregs. Therein, the PD-1/PD-L1 pathway plays a suppressive role to produce cancer immune escape, while the LAG3/MHC-II, Tim-3/galectin 9, and CTLA-4/(CD80, CD86) pathways also contribute to this process. This figure was drawn with Adobe Illustrator CS5. TCR, T-cell receptor; MHC, major histocompatibility complex; APC, antigen-presenting cell; PD-1, programmed cell death protein 1; PD-L1, programmed death-ligand 1; CTLA-4, cytotoxic T Iymphocyte associated antigen-4; Tim-3, T-cell immunoglobulin and mucin domain-3; LAG3, Iymphocyte activation gene 3; TGF- $\beta$, transforming growth factor beta.

expression of CTLA-4 after being co-cultured with stably HBVtransfected human hepatoma cell lines (36).

Resident memory $\mathrm{T}$ cells (Trms) were also enriched in the TME of HBV-related HCC. In these cells, exhaustion markers, such as PD-1, LAG3, TIM-3, and CTLA-4, were more highly expressed, and expression of multiple pro-inflammatory markers, including IFN- $\gamma$, IL-17a, granzyme B, and TNF- $\alpha$, was lower (35). Trms were more function-suppressive and exhausted in virus-positive HCC than those in virus-free HCC. In addition, the immunosuppressive status of insufficient TNF- $\alpha$ and IFN$\gamma$ expression did not change in PD-1-expressing Trms from HBV-related HCC patients after phorbol myristate acetate (PMA)/ionomycin stimulation (35).

The percentages of myeloid-derived suppressor cells (MDSCs) were found to be higher in HBV-infected HCC patients (37, 38). MDSCs promoted a continuous immune-suppressive effect, along with persistent HBV infection and HCC progression (39). These cells could regulate the immune response in chronic HBVinfected patients via PD-1 induced IL-10 (40). They could also induce $\mathrm{CD}^{+}{ }^{+} \mathrm{CD}_{2}{ }^{+} \mathrm{FOXP}^{+}{ }^{+}$Tregs and exhausted $\mathrm{CD}^{+}{ }^{+} \mathrm{T}$ cells and inhibit NK cells in HCC $(41,42)$.

In the past, young patients were regarded as immunotolerant for HBV infection. A study aiming to explore the T-cell tolerance immune profile of young $\mathrm{HBV}$-infected persons found that effector/inflammatory cytokines produced by $\mathrm{T}$ cells, including IFN- $\gamma$, TNF- $\alpha$, IL-17A, and IL-22, were significantly higher in such patients with chronic hepatitis $\mathrm{B}$ infection than in healthy individuals (43). The frequency of PD- ${ }^{+}$CD127 low-CD8 ${ }^{+} \mathrm{T}$ cells increased with age in patients infected with chronic hepatitis $\mathrm{B}$, and a less-compromised HBV-specific T-cell repertoire was also increasingly detected in young patients compared with adult patients with chronic infection (43). Therefore, the long process of infection may lead to a progressive state of T-cell exhaustion and excessive production of immunosuppressionrelated cytokines.

Blocking the corresponding immunosuppressed signal could recover the function of immune cells and improve immune reaction. One study found that $\mathrm{PD}-\mathrm{L} 1$ blockade yielded an 
2-fold increase in HBV-specific T cells, vs. incubation with isotype control $(12,44)$. Not only was HBV-specific $\mathrm{CD}^{+}$and CD8 ${ }^{+}$T-cell response improved upon incubation with anti-PDL1, but IL-2 and IFN- $\gamma$ secretion and proliferation of HBVspecific $\mathrm{CD}^{+}$cells were likewise recovered via PD-L1 blockade. In addition, $\mathrm{HBcAg}$-specific IFN- $\gamma$ production was increased after anti-PD-1 monoclonal antibody used in intrahepatic $\mathrm{T}$ lymphocytes (45). Immunosuppression caused by PD-1 ${ }^{+}$Tregs could be reversed with PD-1 blockade (35), and so could the exhaustion of intrahepatic CD ${ }^{+} \mathrm{T}$ cells by combined PD- 1 and CTLA-4 inhibition (26).

Similar to HBV, HCV infection blocked or altered host immune responses, and resulted in chronic inflammation status (46). In HCV related HCC, tumor tissue was reported to be more vascularized than those of HCC with HBV infection $(47,48)$. A recent research revealed that different tumorinfiltrating leukocytes composition in different subtypes of HCC. M0 macrophage and neutrophil cells were found to predominate in $\mathrm{HCV}^{+}$tumor, and resting memory $\mathrm{CD}_{4}^{+}$ $\mathrm{T}$ cells, activated memory $\mathrm{CD}^{+}{ }^{+} \mathrm{T}$ cells, activated NK cells, resting dendritic cells, and resting mast cells were significantly higher in $\mathrm{HBV}^{+}$tumor tissue contrast with non-tumor samples (49). The significantly elevated MDSCs were found in $\mathrm{HCV}^{+} \mathrm{HCC}$ especially in advanced stage HCC, and positively correlated with HCV viral load (50). Similarly, the proportion of Treg cells, acting the immunosuppressed role, was also significantly higher in $\mathrm{HCV}$ related $\mathrm{HCC}$, especially in the recurrence subset (51). $\mathrm{CD}^{+} \mathrm{T}$ cells and $\mathrm{T}$-cell stimulatory activity of dendritic cells were significantly decreased in HCV related HCC patients $(50,52)$. The increased $\mathrm{CD} 4{ }^{+} \mathrm{CD} 57^{+}$ $\mathrm{T}$ cells in peripheral blood lymphocytes were associated with tumor progression and had a significant inverse correlation with IFN- $\gamma$-producing capability (53). Additionally, HCVHCC patients generated significant higher values for both IL10 , IL-18, and TGF- $\beta$ (54, 55). HCV-HCC patients present immunosuppressed status like HBV infected HCC, and future researches should be carried out to explore the interplay and specific function of immune cells in TME and have transcriptome analyses of represented cell subsets using advanced single-cell sequencing technology.

In summary, the TME of HBV-related HCC is considered to be more immunosuppressive and exhausted than that of non HBV-related HCC (35). As the hotspot of immunotherapy, the PD-1/PD-L1 pathway has gradually become the most important therapeutic target for rescuing immune cells and avoiding tumor progression.

\section{EFFICACY EVALUATION OF ANTI-PD-1/PD-L1 THERAPY \\ Efficacy of PD-1/PD-L1 Inhibitors in HBV-related HCC}

Currently, clinical trials are ongoing to evaluate the efficacy of PD-1/PD-L1 inhibitors as monotherapy or part of combined therapeutic strategies in HCC patients (Table 1). In HCC patients treated with anti-PD-1/PD-L1 monotherapy, objective response rates (ORRs) ranged from 8 to $20 \%$, and disease control rates (DCRs) ranged from 33 to $73 \%$, except one was $10 \%$ (Table 1). With PD-1/PD-L1 based combination therapy, patients achieved higher ORRs and DCRs (ORR range, 20-50\%; DCR range, 49-100\%).

Irrespective of line of therapy, ORRs of advanced HCC with nivolumab were $15-20 \%$, and a substantial reduction in tumors from baseline was also observed (CheckMate 040) (57). The trial suggested the ORRs of patients infected with HCV, HBV and without viral hepatitis were 20,14 , and $22 \%$, respectively, but these acquired data were not powered for statistical comparisons. In the dose-expansion phase, 6- and 9-month overall survival rates were 84 and $70 \%$, respectively, in $\mathrm{HBV}$-infected patients (57). As for the total study population, 6- and 9-month overall survival rates were, respectively, 83 and $74 \%$. Besides, a part of researches supported the off-label use of nivolumab after failure or intolerance of sorafenib treatment or disease progression (73). A subsequent study of nivolumab as first-line therapy (Checkmate 459) not only confirmed the findings observed with second-line nivolumab, but also demonstrated improved quality of life and reduced treatment burden in advanced HCC. As a primary endpoint, consistent effect on overall survival was also observed in advanced HCC with nivolumab and seemingly profitted more in predefined subgroup of HBV infection (56).

Pembrolizumab (Keytruda; prescribing information at https://www.accessdata.fda.gov/drugsatfda_docs/label/2017/ 125514s015lbl.pdf), another anti-PD-1 monoclonal antibody, was used in a phase 2 trial (KEYNOTE-224) involving advancedHCC patients who had previously been treated with sorafenib. ORR, median progression-free survival rate, and 12-month overall survival rate were $17 \%, 12.9$ months and 54\%, respectively (60). Of note, in the subgroup analysis of viral infection, comparable reductions of target lesions from baseline were observed in patients with or without $\mathrm{HBV}$ or HCV infection at the rates of 57 and $58 \%$, respectively (60). In phase 3 study (Keynote 240 ), ORR was $18 \%$ and $4 \%$ for pembrolizumab vs. placebo at final analysis (one-sided $P<0.001$ ), and in Asian subgroup, ORR was $21 \%$ for pembrolizumab and $2 \%$ for placebo $(P<0.001)$. Notably, HBV infection status was much higher in Asian subgroup (Asian: 51\% vs. overall: 25\%) $(61,74)$.

In China, 217 HCC patients intolerant of first-line treatment or with progressive disease were treated with SHR-1210 (camrelizumab, a fully humanized anti-PD-1 immunoglobulin G4 [IgG4] monoclonal antibody) as second-line treatment (64). Of all of the subjects, 32 (15\%) achieved partial response, and 18 patients remained effective at the cutoff point. The 6-month overall survival rate was $74 \%$; the median overall survival was not reached by the time of preliminary analysis. It is noteworthy that $89 \%$ of patients were infected with $\mathrm{HBV}$ and most had serious disease status, including extrahepatic metastasis and alpha-fetoprotein (AFP) $\geq 400 \mathrm{ng} / \mathrm{mL}$. SHR-1210 monotherapy showed clinical efficacy similar to that of nivolumab and pembrolizumab in this trial. In another open-label, doseescalation/expansion study from China, 94\% of HCC patients achieved a state of disease control and $51 \%$ of patients achieved 6-month progress-free survival using SHR-1210 combined with apatinib (72). Interestingly, these enrolled HCC patients were all 
TABLE 1 | PD-1/PD-L1 blockade efficacy in $\mathrm{HBV}^{+} \mathrm{HCC}$ and total HCC patients.

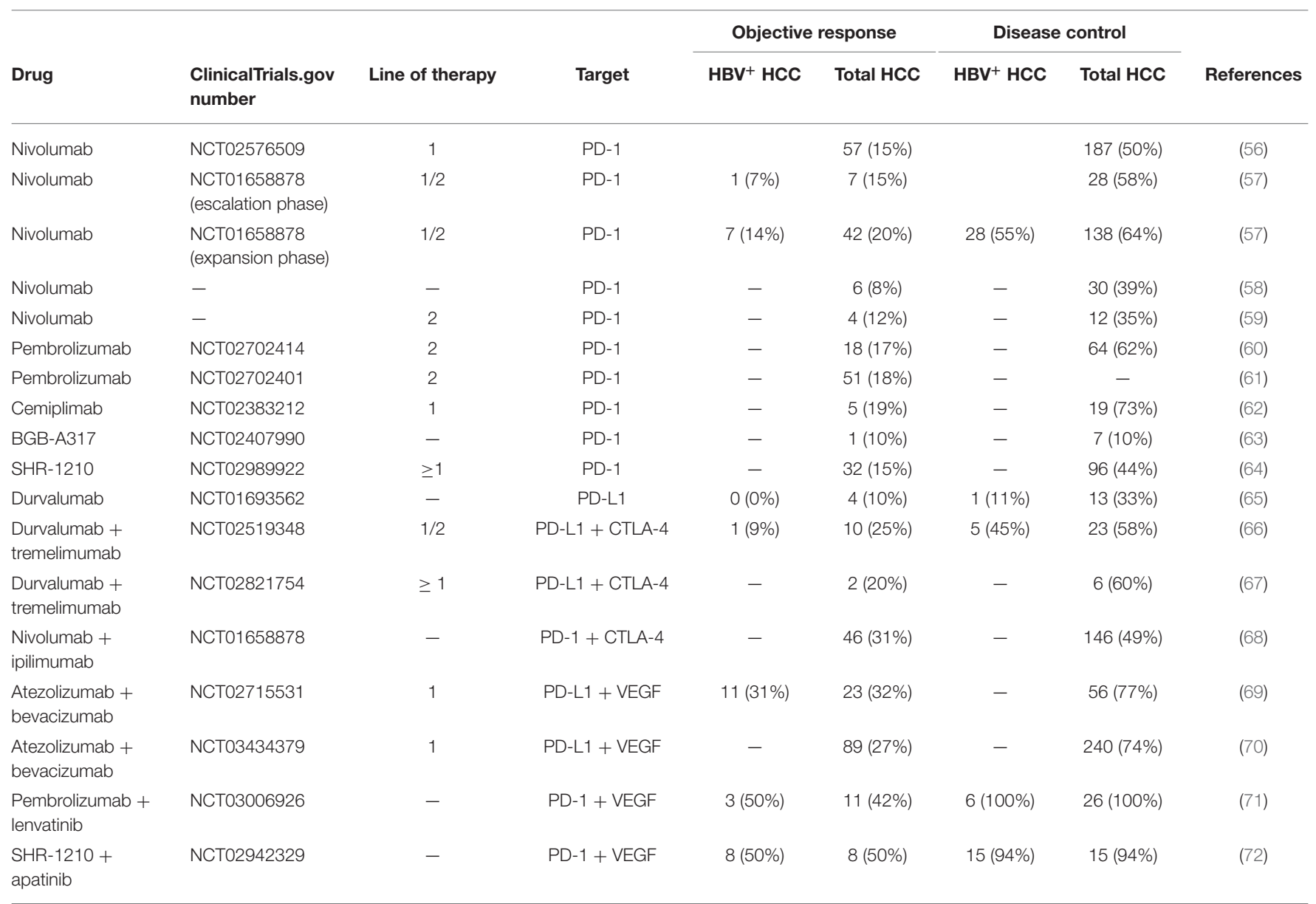

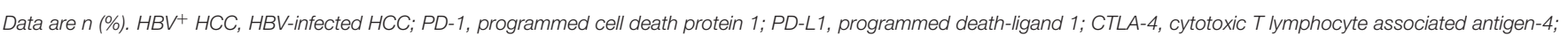
VEGF, vascular endothelial growth factor.

HBV-infected and with heavy tumor burdens, suggesting that the combination therapy likely had greater efficacy than single-agent immunotherapy (Table 1).

Despite these tremendous advances, tumor response to immunotherapy in unselected HCC patients was not commonly elicited, which led to the exploration of combination-based strategies to enhance efficacy. Vascular endothelial growth factor (VEGF) is related to inhibition of dendritic cells maturation in vitro/vivo through the activation of nuclear factor kappalight-chain-enhancer of activated B cells (NF- $\kappa \mathrm{B})$, intratumoral accumulation of immunosuppressive cells of Tregs/MDSCs and inhibition of T-cell infiltration. Anti-VEGF treatment could help tumor vascular normalization and promote immune responses in the TME (75). In a phase Ib study of unresectable or advanced HCC, 31\% HBV-infected patients treated with atezolizumab + bevacizumab achieved objective response, compared with $32 \%$ in the overall study population. After observing a tolerable safety profile and promising anti-tumor activity of this combination in phase $1 \mathrm{~b}$ study, researchers carried out IMbrave150, a global, open-label, Phase 3, randomized study of atezolizumab + bevacizumab vs. sorafenib in unresectable HCC who had not received prior systemic therapy. The study demonstrated statistically significant and clinically meaningful improvement in overall survial and progression-free survival. In corresponding subgroup analysis, patients infected with HBV may profit more than non-virus HCC. Of note, atezolizumab + bevacizumab obviously prolonged median progression-free survival of $\mathrm{HBV}^{+}$ HCC comparing with sorafenib, but this phenomenon did not appear in the population of non-virus HCC (median progressionfree survival, $\mathrm{HBV}^{+} \mathrm{HCC}$ : $6.7 \mathrm{~m}$ vs. $2.8 \mathrm{~m}$; non-virus $\mathrm{HCC}$ : $7.1 \mathrm{~m}$ vs. $5.6 \mathrm{~m})$ (70). In another phase Ib study, focused on lenvatinib + pembrolizumab, a large proportion of patients with unresectable HCC experienced a long-lasting reduction in tumor size, including the HBV-infected patients (71). The combination of two powerful immunotherapy drugs was another trend of HCC treatment. Simultaneously the strong effect of blocking both PD-L1 and CTLA-4 pathway (durvalumab + tremelimumab) was also observed in unresectable HCC but not in $\mathrm{HBV}$ infected subgroup. Only $1 \mathrm{HBV}$ infected patients (9\%) achieved partial response status while $25 \%$ had an objective response in total population (66). The nivolumab + ipilimumab (anti-CTLA-4) combination therapy also presented clinically 


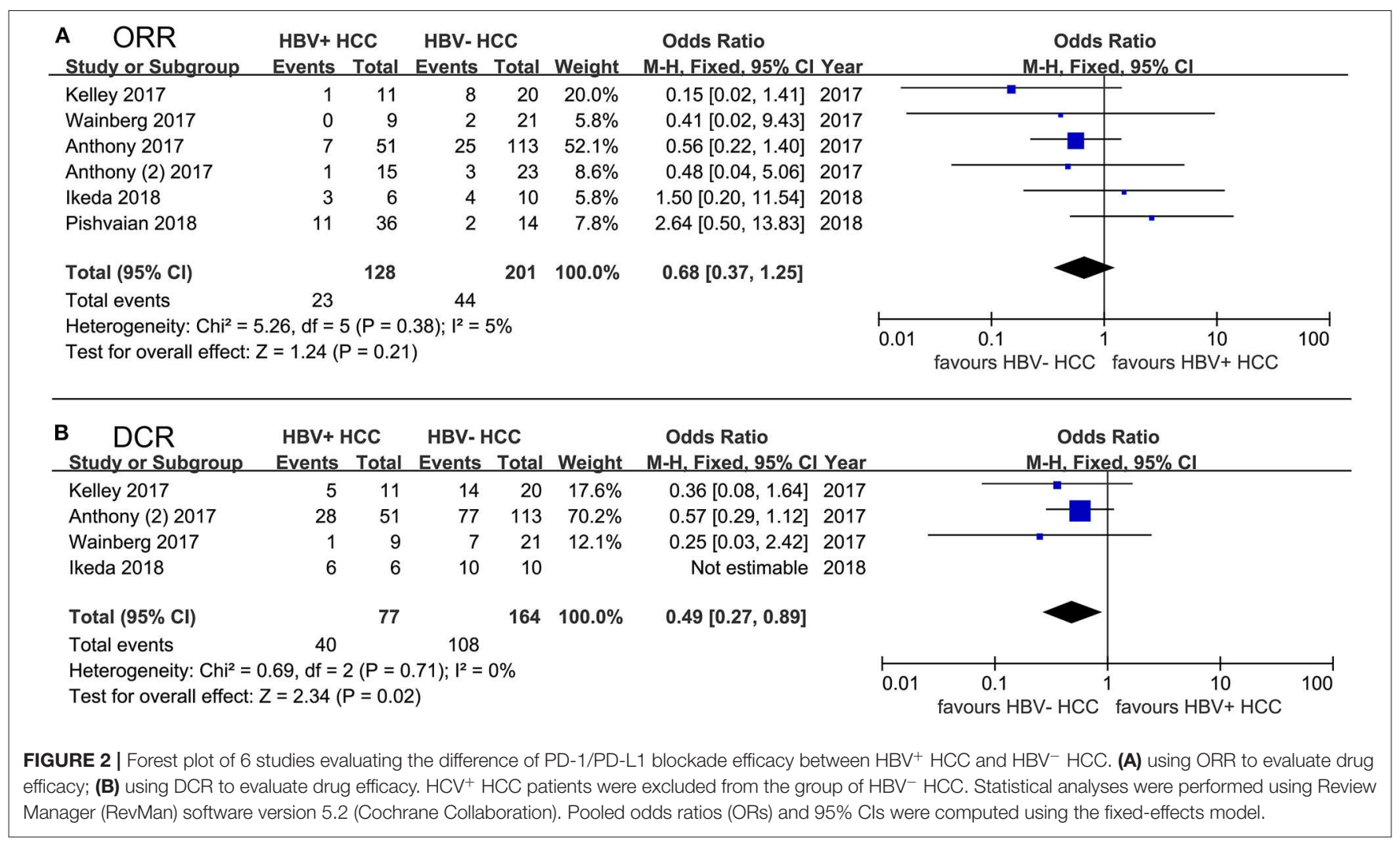

meaningful responses: Overall, ORR: 31\% (7 had a CR); DCR: 49\%; 24-month overall survival rate: $40 \%$ (68).

We performed a pooled analysis to assess the different efficacy of PD-1/PD-L1 inhibitor therapy, including mono- or combined therapy, in both $\mathrm{HBV}^{+} \mathrm{HCC}$ and $\mathrm{HBV}^{-} \mathrm{HCC}$ patients. Of note, $\mathrm{HCV}^{+} \mathrm{HCC}$ patients were excluded from the group of $\mathrm{HBV}^{-}$ $\mathrm{HCC}$, and $\mathrm{HBV}^{-} \mathrm{HCC}$ could be considered as non-viral HCC. We carried out a comprehensive systematic search for published literature in the PubMed and EMBASE databases. Additionally, we acquired partial data from posters, presentations, and meeting abstracts of the American Society of Clinical Oncology (ASCO) and the European Society of Medical Oncology (ESMO). The search strategy and selection criteria for our pooled analysis are provided in "Supplemental Methods." We extracted or calculated odds ratios (ORs) to evaluate the strength of the association between drug efficacy and HBV infection. The $I^{2}$ statistic was applied to evaluate the heterogeneity of studies in the pooled analysis and to help choose an appropriate model $\left(I^{2}\right.$ $<50 \%$ : fixed-effects model, $I^{2} \geq 50 \%$ : random-effects model). As expected, $\mathrm{HBV}^{+}$patients achieved ORRs comparable to those of $\mathrm{HBV}^{-} \mathrm{HCC}$ patients (OR, 0.68; 95\% confidence interval [CI], $0.37-1.25 ; P=0.21$; Figure 2 ), and similar results were obtained in the monotherapy and combined-therapy subgroups (data not shown). However, the DCRs of $\mathrm{HBV}^{+}$patients were significantly lower than those of $\mathrm{HBV}^{-}$ones with $\mathrm{PD}-1 / \mathrm{PD}-\mathrm{L} 1$ inhibitor therapy (OR, 0.49; 95\% CI, 0.27-0.89; $P=0.02$; Figure 2), and we observed stable disease more in $\mathrm{HBV}^{-}$patients than in $\mathrm{HBV}^{+}$patients, although not significantly (42\% vs. $\left.38 \%\right)$. In the subgroup of combined-therapy, the DCRs of $\mathrm{HBV}^{+}$patients were also significantly lower than those of $\mathrm{HBV}^{-}$ones (OR, 0.52; 95\% CI, 0.27-0.99; $P=0.05)$. Additionally, we compared drug efficacy of $\mathrm{HCV}^{+} \mathrm{HCC}$ with those in $\mathrm{HBV}^{+} \mathrm{HCC}$ and $\mathrm{HBV}^{-} \mathrm{HCC}$. No significant difference was found in ORRs and DCRs of $\mathrm{HCV}^{+}$ $\mathrm{HCC}$ compared to those in $\mathrm{HBV}^{+} \mathrm{HCC}$ and $\mathrm{HBV}^{-} \mathrm{HCC}$ (all $P$ $>0.05$, Supplemental Table 1).

\section{Antiviral Effect of PD-1/PD-L1 Blockade}

One study showed that adefovir monotherapy could control $\mathrm{HBV}$ viremia but HBsAg seroconversion was not achieved in patients with chronic hepatitis $\mathrm{B}$, while the decreased but remaining number of peripheral Tregs still expressed high levels of PD-1 (76). In an animal model, viremia and antigenemia in woodchucks infected with woodchuck hepatitis virus (WHV) could be controlled via combination therapy containing anti-PDL1 antibody and entecavir (77). Moreover, this combined strategy was better than antiviral treatment alone and incurred no liver damage AEs. PD-1/PD-L1 blockade led to significant HBsAg decline from baseline in virally suppressed chronic hepatitis $B$, and existed anti-HBV effect of PD-1/PD-L1 blockade was proved (78). There were some researches explored the antiviral effect of PD-1 blockade in virally infected HCC patients $(57,58)$. To achieve this goal, researchers assessed serum HBV surface antigen (HBsAg) and anti-HBs from HBV infected patients at baseline and after treatment. Existed but limited antiviral activity was found after treatment with nivolumab. No HBV reactivation was observed, and no patients infected with HBV achieved 
anti-HBs seroconversion, either (57). Similar results were found in $\mathrm{HCV}$-infected patients, none of whom achieved a sustained virological response such as a reduction in HCV RNA levels lasting for 24 weeks (57). In these clinical studies, inclusion criteria included limitation of viral load (e.g., $<100 \mathrm{IU} / \mathrm{mL}$ ) by treatment of antiviral therapy. Thus, the anti-virus effects of checkpoint inhibitors are still in doubt and must be identified.

\section{Potential Signature for Predicting Drug Response}

HCC heterogeneity is an important influence factor on immunotherapy effects; therefore, a potential predictive biomarker could help select patients who will probably benefit from the therapy.

PD-L1, a key check-point molecule, is generally expressed on tumor cells and interact with PD-1 to cause immune tolerance and evasion in TME (79). High PD-L1 expression in tumor cells, peritumoral hepatocytes and peripheral blood are associated with worse prognosis (80-82). And PD-L1 overexpression is positively related to higher levels of AFP, vascular invasion and poor tumor differentiation (81). Upregulating expression of $P D-1$ and $P D-L 1$ in tumor-infiltrating effector $C D 8^{+} \mathrm{T}$ cells is also relevant to disease progression and higher recurrence rates $(44,83)$. In a sense, the PD-L1 expression of tumor could be considered as an index to evaluate the immunosuppression caused by PD-1/PD-L1 axis and predict the efficacy of anti-PD1/PD-L1 therapy. The predictive role of PD-L1 expression has been identified in the treatment of non-small-cell lung cancer (NSCLC) and gastric cancer with pembrolizumab (60). In HCC treated nivolumab, higher ORR was observed in HCC patients with PD-L1 expression on at least $1 \%$ of tumor cells, although not significantly (26\% vs. 19\%) (57). A similar outcome occurred in Keynote 224, response to anti-PD-1 therapy (pembrolizumab) was not associated with PD-L1 expression on tumor cells assessed retrospectively by immunohistochemistry. Of note, combined positive score (CPS) used for assessing not only tumor cells' PDL1 expression but also those in immune cells, was significantly related to ORR and progression-free survival in this study (60). In Checkmate 459, the consistent effect was observed in patients with first-line nivolumab therapy compared to patients treated with sorafenib. And there was a trend toward better overall survial and ORR in patients with PD-L1 $\geq 1 \%$ (56). Thus, the PD-L1 expression related score model has the potential to be a reliable predictor of response to anti-PD-1 therapy.

Interestingly, another study showed that serum soluble PD-L1 (sPD-L1) concentration was several-fold higher in HBV-related HCC than in healthy control, a significant difference, while sPDL1 was positively correlated with tumor PD-L1 expression (84). In addition, higher pre-treatment serum sPD-L1 levels were unfavorable predictors of worse disease-free and overall survival. Zeng et al. suggested that higher PD-L1 levels in peripheral blood was associated with a higher rate of tumor recurrence and progression (85). Because the existing clinical trials of antiPD-1/PD-L1 immunotherapy did not provide enough data on PD-L1 expression in HBV-related HCC subgroup, the potential predictive role of $\mathrm{PD}-\mathrm{L} 1$ should be further investigated in future studies. Based on previous promising observations, we hypothesize that PD-L1 is likely to serve as a predictor for drug efficacy or prognosis in HBV-related HCC.

\section{RELATED MECHANISMS OF DISRUPTING PD-1/PD-L1 BLOCKADE EFFICACY IN $\mathrm{HBV}^{+} \mathrm{HCC}$}

\section{HBV Induced Immune Cell Dysfunction and a Decline in Immune Cell Quantity}

Using intracellular cytokine staining, researchers observed an inverse correlation between levels of T-cell response and viremia levels, implying that decreasing the viremia levels may have a role in enhancing immune responses of $\mathrm{T}$ cells (12). A recent study suggested that patients with low HBV levels have a signature of activated T-cell proliferation (27). Antiviral treatment could alter T-cell function, as $\mathrm{CD}^{+}$tumor-infiltrating lymphocytes from patients who received antiviral treatment (entecavir) did express higher effector T-cell markers and lower T-cell exhaustion markers. Antiviral drugs could activate $\mathrm{T}$ cells and strengthen their immune function, resulting in a better prognosis and decreased recurrence rates of HBV-related $\operatorname{HCC}(27,86,87)$. Peripheral expansion of Treg levels was also negatively correlated with HBV viral load, and the percentage of Tregs expressing PD-1 was significantly decreased when HBV replication was controlled (76). Thus, well-controlled HBV replication was of great importance to restoring immune system function.

\section{Altered Expression of Drug Targets: PD-1/PD-L1}

PD-1 or PD-L1 blockade was applied to break the interaction of PD-1/PD-L1; therefore, sufficient enrichment of PD-L1 in tumor and host cells or PD-1 in immune-related cells was necessary for therapy to be efficacious. A single-nucleotide polymorphism (SNP) based experiment suggested that PD-1 mRNA levels in peripheral blood of $\mathrm{HBV}$-infected patients were sequentially increased from $P D-1$ rs10204525 genotypes GG and AG to AA and that the levels in genotype GG were significantly lower than in genotype AA; however, the results could not be found in the virus-negative group (88). Immunohistochemical (IHC) scores of PD-1 expression in tumor tissues and adjacent tissues from HCC patients with $P D-1^{+}$rs10204525 genotype AA were significantly higher than those from patients with genotypes AG and GG. The same results were observed in liver tissues of cirrhotic patients. PD-1 mRNA levels in peripheral-blood nuclear cells were found to be sequentially increased with the elevation of HBV DNA levels (89). The genotype determination of PD-1 rs10204525 might become a potential biomarker of response to anti-PD-1/PD-L1 therapies.

\section{Tumor T-cell Receptor (TCR) Diversity}

Virus-specific $\mathrm{T}$ cells were thought to be protective factors in the process of HBV infection, as patients with chronic HBV infection always had insufficient and dysfunctional HBV-specific T cells. Therefore, researchers engineered T cells to express specific HBVspecific TCRs through messenger RNA (mRNA) electroporation, 
enabling them to lyse HBV-producing hepatoma cells in vitro. In vivo, HBV-specific T cells expressing either the HBV-specific envelope or core TCR complex led to an $80-90 \%$ reduction of progressive viremia in mice after injections $3 \times /$ day for 12 days; longitudinal changes in viremia relative to baseline were determined at days 4,8 , and $12(90)$. That is to say, T cells with specific TCRs were confirmed as targeting their corresponding antigens. In HBV-related HCC, data from high-throughput sequencing (HTS) technology showed that TCR diversity in tumors was higher than in adjacent non-tumor tissues. Limited overlap and rarely shared HCC clonal neo-antigens were found between these two kinds of tissues (24). Recently, autologous $\mathrm{T}$ cells were engineered to express TCR-specific epitopes from integrated HBV DNA in order to achieve antitumor efficacy in HBV-associated HCC. In addition, engineering HBV-specific T cells based on HBV transcriptomes of HCC cells was thought to be useful for personalized immunotherapy (91).

\section{SIDE EFFECT EVALUATION OF ANTI-PD-1/PD-L1 THERAPY \\ Identifying Treatment-related Adverse Events (TRAEs)}

When making treatment decisions for patients with advanced cancer, the oncologists should take the drug-related side effect and toxicity into consideration and adjust treatment strategy to decease the occurrence of TRAEs and mortality risk. AntiPD-1/PD-L1 pathway therapy has been identified as safe in several advanced cancers including melanoma and NSCLC, and a systematic meta-analysis revealed that PD-1/PD-L1 inhibitor was in lower risk and better tolerated by comparing incidences of all and high-grade adverse events (AEs) between the PD1/PD-L1 inhibitors group and the chemotherapy group (92). We assessed the safety of PD-1/PD-L1 inhibitor blockade based on data from about a dozen clinical trials (Table 2) to show that PD-1/PD-L1 blockade provided a similar and accepted safety profile for advanced-HCC patients vs. those with other malignant tumors. The most common TRAEs of PD-1/PD-L1 blockade monotherapy or combination therapy were fatigue, rash, pruritus, diarrhea, nausea, and increased levels of aspartate aminotransferase (AST) and alanine aminotransferase (ALT). Similar to previous toxicity assessments in other malignant tumors, TRAES were concentrically distributed across the categories of fatigued physical function, dermatological signs and elevated laboratory indices for liver function. Increased AST and ALT levels occurred more frequently than other Grade $\geq 3$ TRAEs.

\section{Safety Assessment in Conditions of HBV Infection}

A study combining PD-L1 and CTLA-4 blockade showed that most TRAEs in $\mathrm{HBV}^{+} \mathrm{HCC}$ were dermatological signs and elevated laboratory indices for liver function, including pruritus, rash, increased ALT level, and increased AST level (66). Of immune-related AEs induced by immune checkpoint blockade, dermatological toxicity, including rash and pruritus were the most common, representative and earliest-onset (93). Total prior data for $\mathrm{HCC}$ (both $\mathrm{HBV}^{+}$and $\mathrm{HBV}^{-}$) indicated that dermatological toxicity was common but mild in anti-PD-1/PDL1 therapy (Table 2), and the symptoms could be controlled by classical topical corticosteroid creams, peroral antipruritics or intravenous corticosteroid in more-severe cases.

Unlike the usual treatment-related symptoms, hepatic safety events should be emphasized in viral-infected subjects. Studies show that changes in AST and ALT levels are not consistent with typical radiographic liver findings; therefore, regular monitoring of liver function is important (94). AST and ALT, sensitive markers of acute hepatocyte damage, are frequently monitored in HBV-infected HCC with PD-1/PD-L1 blockade. And previous studies suggested that lack of prophylactic antiviral therapy was the most critical risk factor which contributed to HBV reactivation (95). To decrease the incidence of related AEs, HBVinfected patients involved in cohort studies were required to receive effective antiviral therapy to reach a low viral load, such as $<100 \mathrm{IU} / \mathrm{mL}(57,60)$. Fortunately, in contrast with prior CTLA-4 based research, HBV-infected patients who received nivolumab treatment did not demonstrate any new or unique safety signals (57). Because of controllable liver dysfunction in HCC patients and regular supervision of transaminase indicators, few patients suffered immune-mediated hepatitis and no $\mathrm{HBV}$ or $\mathrm{HCV}$ viral flares were observed in patients receiving anti-PD-1/PDL1 therapy $(57,60)$. Symptomatic TRAEs comparable to those reported in existing studies were found in patients with and without $\mathrm{HCV}$ or $\mathrm{HBV}$ infection. That is to say, HCC patients with well-controlled HBV viral risk factors could obtain safety profiles similar to those of noninfected participants and their risk of fulminant hepatitis could be lowered considerably.

\section{CONCLUSIONS}

The HBV infection-related HCC immunosuppressed tumor microenvironment features upregulation of $\mathrm{PD}-1$ in $\mathrm{CD}^{+} \mathrm{T}$ cells; long-lasting inhibition of Tregs via higher levels of IL10 and TGF- $\beta$ secretion; and the co-inhibitory signal of LAG3, TIM-3, and CTLA-4. Along with the above immunosuppressive factors, the PD-1/PD-L1 signaling pathway is thought to be the most important and widely adopted mechanism in the diagnosis and treatment of HCC patients with HBV infection.

In this study, we evaluated the safety and efficacy of PD-1/PDL1 blockade immunotherapy, and also summarized the general differences between $\mathrm{HBV}$ related $\mathrm{HCC}$ and virus unrelated HCC (Table 3). Similar to patients with other tumor types, we observed acceptable toxicity and promising outcomes in HCC patients treated with $\mathrm{PD}-1 / \mathrm{PD}-\mathrm{L} 1$ antibodies. According to our pooled analysis, ORRs of $\mathrm{HBV}^{+} \mathrm{HCC}$ patients treated with anti-PD-1/PD-L1 immunotherapy were comparable to those of $\mathrm{HBV}^{-}$ones, whereas DCRs of $\mathrm{HBV}^{+}$patients were significantly lower. Based on our results, PD-1/PD-L1 blockade seemed to achieve slightly worse efficacy in $\mathrm{HBV}^{+} \mathrm{HCC}$ patients than in $\mathrm{HBV}^{-} \mathrm{HCC}$ ones. Nevertheless, when they were receiving a combination of anti-PD-1/PD-L1 and VEGF therapy, HBV- 
TABLE 2 | Safety and tolerability of PD-1/PD-L1 monotherapy or combination therapy in total HCC patients and $\mathrm{HBV}^{+}$subgroup.

\begin{tabular}{|c|c|c|c|c|c|c|c|c|c|}
\hline Drug & $\begin{array}{l}\text { ClinicalTrials.gov } \\
\text { number }\end{array}$ & Target & $\mathrm{HBV}^{+} \mathrm{HCC}(\%)$ & $\begin{array}{l}\text { Safety evaluation in } \\
\mathrm{HBV}^{+} \mathrm{HCC}\end{array}$ & All-grade TRAEs & Grade $\geq 3$ TRAEs & $\begin{array}{l}\text { All-grade TRAES } \\
\text { (details) }\end{array}$ & $\begin{array}{l}\text { Grade } \geq 3 \text { TRAEs } \\
\text { (details) }\end{array}$ & References \\
\hline Nivolumab & $\begin{array}{l}\text { NCT01658878 } \\
\text { (escalation phase) }\end{array}$ & PD-1 & 15 (31\%) & $\begin{array}{l}\text { Comparable } \\
\text { symptomatic TRAEs to } \\
\text { total HCC; No new } \\
\text { safety signals }\end{array}$ & 40 (83\%) & $12(25 \%)$ & $\begin{array}{l}{ }^{*} \text { Rash }(23 \%), \text { AST } \\
\text { increase }(21 \%), \text { lipase } \\
\text { increase }(21 \%), \\
\text { pruritus (19\%), } \\
\text { amylase increase } \\
(19 \%), \text { ALT increase } \\
(15 \%) \text {, diarrhea (10\%), } \\
\text { decreased appetite } \\
(10 \%)\end{array}$ & $\begin{array}{l}\text { Lipase increase } \\
(13 \%), A S T \text { increase } \\
(10 \%), A L T \text { increase } \\
(6 \%), \text { amylase } \\
\text { increase }(4 \%) \text {, } \\
\text { fatigue (1\%), anemia } \\
(1 \%)\end{array}$ & (57) \\
\hline Nivolumab & $\begin{array}{l}\text { NCT01658878 } \\
\text { (expansion phase) }\end{array}$ & PD-1 & $51(24 \%)$ & $\begin{array}{l}\text { Comparable } \\
\text { symptomatic TRAEs to } \\
\text { total HCC; No } \\
\text { reactivation of HBV; No } \\
\text { instances of anti-HBs } \\
\text { seroconversion; No } \\
\text { new safety signals }\end{array}$ & - & 40 (19\%) & $\begin{array}{l}\text { Comparable to that } \\
\text { observed in the } \\
\text { dose-escalation phase }\end{array}$ & - & (57) \\
\hline Nivolumab & NCT02576509 & PD-1 & $116(31 \%)$ & - & - & $81(22 \%)$ & $\begin{array}{l}\text { *Skin (28\%), hepatic } \\
(17 \%), \text { endocrine } \\
(13 \%) \text {, Gastrointestinal } \\
(9 \%), \\
\text { Hypersensitivity/infusion } \\
\text { reaction (8\%) }\end{array}$ & $\begin{array}{l}\text { *Hepatic (10\%), Skin } \\
\text { (2\%), } \\
\text { Gastrointestinal (2\%) }\end{array}$ & (56) \\
\hline Nivolumab & - & PD-1 & - & - & - & $2(6 \%)$ & - & $\begin{array}{l}\text { Bullous lichenoid } \\
\text { drug eruption (3\%), } \\
\text { hepatitis (3\%) }\end{array}$ & (59) \\
\hline Nivolumab & - & PD-1 & 56 (74\%) & $\begin{array}{l}\text { No observed HBV } \\
\text { reactivation }\end{array}$ & - & $2(3 \%)$ & $\begin{array}{l}\text { Liver dysfunction } \\
(21 \%), \text { pruritus (16\%), } \\
\text { anorexia (16\%), } \\
\text { nausea (13\%), fatigue } \\
(8 \%)\end{array}$ & $\begin{array}{l}\text { liver dysfunction } \\
(1 \%), \text { diabetes (1\%) }\end{array}$ & (58) \\
\hline Pembrolizumab & NCT02702414 & PD-1 & $22(21 \%)$ & $\begin{array}{l}\text { No cases of flares of } \\
\text { HBV; Few } \\
\text { immune-mediated } \\
\text { hepatitis }\end{array}$ & 76 (73\%) & $27(26 \%)$ & $\begin{array}{l}{ }^{*} \text { Fatigue }(21 \%), \\
\text { increased AST (13\%), } \\
\text { pruritus (12\%), } \\
\text { diarrhea }(11 \%) \text {, rash } \\
(10 \%)\end{array}$ & $\begin{array}{l}\text { Increased AST (7\%), } \\
\text { fatigue (4\%), } \\
\text { increased ALT (4\%) }\end{array}$ & (60) \\
\hline Pembrolizumab & NCT02702401 & PD-1 & - & No cases of HBV flare & - & - & - & - & (61) \\
\hline $\begin{array}{l}\text { Camrelizumab } \\
\text { (SHR-1210) }\end{array}$ & NCT02989922 & PD-1 & $181(83 \%)$ & $\begin{array}{l}\text { High HBV infection rate } \\
(84 \%) \text {; Similar safety } \\
\text { profile with total HCC }\end{array}$ & - & $47(22 \%)$ & $\begin{array}{l}{ }^{*} \text { RCEP }(67 \%), \\
\text { increased AST (25\%), } \\
\text { increased ALT (24\%), } \\
\text { proteinuria (23\%), } \\
\text { increased Blood } \\
\text { bilirubin (17\%) }\end{array}$ & $\begin{array}{l}{ }^{*} \text { Increased AST } \\
(5 \%), \text { decreased } \\
\text { neutrophil count } \\
(3 \%)\end{array}$ & (64) \\
\hline BGB-A317 & NCT02407990 & PD-1 & - & - & $2(18 \%)$ & $0(0 \%)$ & $\begin{array}{l}\text { Fatigue (9\%), rash } \\
(9 \%)\end{array}$ & - & (63) \\
\hline
\end{tabular}


TABLE 2 | Continued

\begin{tabular}{|c|c|c|c|c|c|c|c|c|c|}
\hline Drug & $\begin{array}{l}\text { ClinicalTrials.gov } \\
\text { number }\end{array}$ & Target & $\mathrm{HBV}^{+} \mathrm{HCC}(\%)$ & $\begin{array}{l}\text { Safety evaluation in } \\
\mathrm{HBV}^{+} \mathrm{HCC}\end{array}$ & All-grade TRAEs & Grade $\geq 3$ TRAEs & $\begin{array}{l}\text { All-grade TRAES } \\
\text { (details) }\end{array}$ & $\begin{array}{l}\text { Grade } \geq 3 \text { TRAEs } \\
\text { (details) }\end{array}$ & References \\
\hline Cemiplimab & NCT02383212 & PD-1 & - & - & - & - & $\begin{array}{l}\text { Fatigue (27\%), } \\
\text { decreased appetite } \\
(23 \%), \text { increased AST } \\
(23 \%) \text {, abdominal pain } \\
(23 \%), \text { pruritus (23\%), } \\
\text { dyspnea (23\%) }\end{array}$ & - & (62) \\
\hline Durvalumab & NCT01693562 & PD-L1 & $9(23 \%)$ & - & 32 (80\%) & $8(20 \%)$ & $\begin{array}{l}\text { *Fatigue (28\%), } \\
\text { pruritus (25\%), } \\
\text { increased AST (23\%), } \\
\text { decreased appetite } \\
(13 \%) \text {, increased ALT } \\
(10 \%) \text {, diarrhea (10\%), } \\
\text { nausea (10\%) }\end{array}$ & $\begin{array}{l}\text { *Increased AST } \\
(8 \%), \text { Increased ALT } \\
(5 \%)\end{array}$ & (65) \\
\hline $\begin{array}{l}\text { Atezolizumab } \\
+ \\
\text { bevacizumab }\end{array}$ & NCT02715531 & $\begin{array}{l}\text { PD-L1 }+ \\
\text { VEGF }\end{array}$ & $51(50 \%)$ & No new safety signals & $84(82 \%)$ & $30(27 \%)$ & $\begin{array}{l}\text { Decreased appetite } \\
(28 \%), \text { fatigue }(20 \%) \text {, } \\
\text { rash (20\%), pyrexia } \\
(20 \%)\end{array}$ & Hypertension (10\%) & (69) \\
\hline $\begin{array}{l}\text { Atezolizumab } \\
+ \\
\text { bevacizumab }\end{array}$ & NCT03434379 & $\begin{array}{l}\text { PD-L1+ } \\
\text { VEGF }\end{array}$ & 164 (49\%) & - & $276(84 \%)$ & $117(36 \%)$ & $\begin{array}{l}\text { *Hypertension (nearly } \\
30 \% \text { ); diarrhoea, } \\
\text { decreased appetite, } \\
\text { pyrexia, increased ALT } \\
\text { (all > 10\%) }\end{array}$ & *Hypertension (10\%) & (70) \\
\hline $\begin{array}{l}\text { Pembrolizumab } \\
+ \text { lenvatinib }\end{array}$ & NCT03006926 & $\begin{array}{l}\text { PD-1 }+ \\
\text { VEGF }\end{array}$ & $8(27 \%)$ & $\begin{array}{l}\text { No unexpected safety } \\
\text { signals }\end{array}$ & 28 (93\%) & $18(60 \%)$ & $\begin{array}{l}\text { Decreased appetite } \\
(53 \%) \text {, hypertension } \\
(53 \%) \text {, diarrhea (43\%), } \\
\text { fatigue (40\%), } \\
\text { dysphonia (30\%), } \\
\text { proteinuria (30\%) }\end{array}$ & $\begin{array}{l}\text { *Hypertension } \\
(17 \%), \text { increased } \\
\text { AST }(17 \%), \text { WBC } \\
\text { count decreased } \\
\text { (13.3\%), } \\
\text { hyponatremia (10\%) }\end{array}$ & (71) \\
\hline $\begin{array}{l}\text { Nivolumab + } \\
\text { ipilimumab }\end{array}$ & NCT01658878 & $\begin{array}{l}\text { PD-1+ } \\
\text { CTLA-4 }\end{array}$ & - & - & - & $148(37 \%)$ & $\begin{array}{l}\text { Pruritus, rash (data not } \\
\text { shown) }\end{array}$ & - & (68) \\
\hline $\begin{array}{l}\text { Durvalumab + } \\
\text { tremelimumab }\end{array}$ & NCT02519348 & $\begin{array}{l}\text { PD-L1 + } \\
\text { CTLA-4 }\end{array}$ & $11(28 \%)$ & $\begin{array}{l}\text { TRAEs: Pruritus (27\%), } \\
\text { diarrhea (27\%), } \\
\text { increased ALT }(27 \%), \\
\text { increased AST (27\%), } \\
\text { increased lipase (18\%), } \\
\text { rash (18\%), increased } \\
\text { amylase (18\%), } \\
\text { pancreatitis (9\%) } \\
\text { No unexpected } \\
\text { safety signals }\end{array}$ & $26(65 \%)$ & $10(25 \%)$ & $\begin{array}{l}\text { Fatigue (28\%), pruritus } \\
(23 \%), \text { increased ALT } \\
\text { (20\%), increased AST } \\
\text { (18\%), increased } \\
\text { lipase (15\%) }\end{array}$ & $\begin{array}{l}\text { Increased AST } \\
\text { (10\%), increased } \\
\text { lipase (10\%), } \\
\text { increased ALT (5\%) }\end{array}$ & (66) \\
\hline $\begin{array}{l}\text { Durvalumab + } \\
\text { tremelimumab }\end{array}$ & NCT02821754 & $\begin{array}{l}\text { PD-L1 + } \\
\text { CTLA-4 }\end{array}$ & - & - & - & - & - & - & (67) \\
\hline
\end{tabular}

Data are expressed as $n(\%)$ or event (\%). TRAE, treatment-related adverse event; TRSAEs, treatment-related serious adverse event; AST, aspartate aminotransferase; ALT, alanine aminotransferase; RCEP, reactive cutaneous capillary endothelial proliferation; DT, discontinued treatment. * partial AEs with highest incidence are displayed. 
TABLE 3 | General differences between HBV related HCC and virus unrelated HCC.

\begin{tabular}{|c|c|c|}
\hline Aspect & $\begin{array}{l}\text { HBV }^{+} \text {HCC's characteristics } \\
\text { compared to virus unrelated ones }\end{array}$ & References \\
\hline \multicolumn{3}{|c|}{ Disease state/feature } \\
\hline HBV itself & $\begin{array}{l}\text { Strong variability; Viral heterogeneity } \\
\text { accumulation; Hard to eradicate }\end{array}$ & (96) \\
\hline $\begin{array}{l}\text { HBV-induced } \\
\text { mechanism }\end{array}$ & $\begin{array}{l}\text { Chronic inflammation; } \\
\text { Immune-mediated hepatocyte } \\
\text { damage; higher rate of chromosomal } \\
\text { alterations; p53 inactivation; } \\
\text { WNT/b-catenin pathway inactivation; } \\
\text { Oncogenic HBx protein; Insertional } \\
\text { mutagenesis; Genomic instability }\end{array}$ & $(97,98)$ \\
\hline $\begin{array}{l}\text { Tumor } \\
\text { microenvironment }\end{array}$ & $\begin{array}{l}\text { Activated PD-1/PD-L1 signaling } \\
\text { pathway; Co-inhibitory signal of } \\
\text { LAG3, TIM-3, and CTLA-4; } \\
\text { Exhausted CD8 }{ }^{+} \text {T cells; } \\
\text { Immunosuppressive role of Tregs; } \\
\text { Function-suppressive Trms. Higher } \\
\text { levels of IL-10 and TGF- } \beta \text { secretion }\end{array}$ & $(22,26-36)$ \\
\hline \multicolumn{3}{|c|}{ Performance when treated with PD-1/PD-L1 immunotherapy } \\
\hline Efficacy & $\begin{array}{l}\text { Comparable ORR and lower DCR } \\
\text { (pooled analysis) }\end{array}$ & \\
\hline $\begin{array}{l}\text { Safety profile and } \\
\text { toxicity }\end{array}$ & $\begin{array}{l}\text { Comparable symptomatic TRAEs to } \\
\text { total HCC; No reactivation of HBV; No } \\
\text { cases of flares of HBV; No instances } \\
\text { of anti-HBs seroconversion; Few } \\
\text { immune-mediated hepatitis }\end{array}$ & $(57,60,61,64)$ \\
\hline New safety signal & $\begin{array}{l}\text { No new safety signals (consist with } \\
\text { virus unrelated } \mathrm{HCC} \text { ) }\end{array}$ & $(57,66,69,71)$ \\
\hline Antiviral effect & $\begin{array}{l}\text { Existed anti-HBV effect of } \\
\text { PD-1/PD-L1 blockade in previous } \\
\text { study; No HBV reactivation in } \mathrm{HBV}^{+} \\
\text {HCC with low viral loads }\end{array}$ & $(57,58,60,78)$ \\
\hline
\end{tabular}

LAG3, Iymphocyte-activation gene 3; TIM-3, T-cell immunoglobulin and mucin domain3; CTLA-4, cytotoxic T lymphocyte associated antigen-4; Tregs, regulatory T cells; Trms, resident memory T cells; ORR, objective response rate; $D C R$, disease control rate; TRAE, treatment-related adverse event.

related HCC patients achieved ORRs and DCRs as high as those of $\mathrm{HBV}^{-}$patients. However, even the existing but limited antivirus effect was found due to the HBV serological indicator. Due to well-controlled viral loads and routine antivirus therapy in current studies, the antiviral activity of anti-PD-1/PD-L1

\section{REFERENCES}

1. Bray F, Ferlay J, Soerjomataram I, Siegel RL, Torre LA, Jemal A. Global cancer statistics 2018: GLOBOCAN estimates of incidence and mortality worldwide for 36 cancers in 185 countries. CA Cancer J Clin. (2018) 68:394424. doi: $10.3322 /$ caac. 21492

2. Siegel RL, Miller KD, Jemal A. Cancer statistics, 2016. CA Cancer J Clin. (2016) 66:7-30. doi: 10.3322/caac.21332

3. Xie Y. Hepatitis B virus-associated hepatocellular carcinoma. Adv Exp Med Biol. (2017) 1018:11-21. doi: 10.1007/978-981-10-5765-6_2

4. Zhu RX, Seto WK, Lai CL, Yuen MF. Epidemiology of hepatocellular carcinoma in the Asia-Pacific region. Gut Liver. (2016) 10:3329. doi: $10.5009 /$ gnl15257 therapy should be identified in a specially designed study in the future. The predictive value of PD-L1 expression for PD1 blockade efficacy has been identified in not only melanoma and NSCLC but also HCC $(57,60,99)$. PD-L1 expression level is commonly higher in HBV-related HCC, and the predictive effect of PD-L1 expression requires investigation in $\mathrm{HBV}$ related cohorts.

Factors, including HCC heterogeneity, HBV replication, and drug target, were related to disruption of $\mathrm{PD}-1 / \mathrm{PD}-\mathrm{L} 1$ blockade efficacy in $\mathrm{HBV}^{+} \mathrm{HCC}$ patients. Therefore, researchers should consider adjusting the cure strategy when the underlying mechanism is further clarified and explained. Finally, there remains a lack of valuable predictive biomarkers to monitor treatment effectiveness or choose the right patients to benefit from anti-PD-1/PD-L1 blockade immunotherapy, and further studies in these areas must be carried out in the future.

\section{AUTHOR CONTRIBUTIONS}

$\mathrm{BL}, \mathrm{WF}$, and WJ contributed to the conception, design, and final approval of the submitted version. BL, CY, XC, QF, HZ, and LL contributed to the collection and interpretation of data. ZT, YZ, $\mathrm{PZ}$, and JZ contributed to the completion of figures and tables. $\mathrm{BL}, \mathrm{CY}$, and WF contributed to writing the paper. All the authors have read and approved the final manuscript.

\section{FUNDING}

This work was supported by the National Natural Science Foundation of China Youth Program (Grant No. 81802350 and No. 81802355).

\section{ACKNOWLEDGMENTS}

We thank LetPub (www.letpub.com) for its linguistic assistance during the preparation of this manuscript.

\section{SUPPLEMENTARY MATERIAL}

The Supplementary Material for this article can be found online at: https://www.frontiersin.org/articles/10.3389/fimmu. 2020.01037/full\#supplementary-material 
9. Goodman A, Patel SP, Kurzrock R. PD-1-PD-L1 immune-checkpoint blockade in B-cell lymphomas. Nat Rev Clin Oncol. (2017) 14:20320. doi: 10.1038/nrclinonc.2016.168

10. Fisicaro P, Valdatta C, Massari M, Loggi E, Biasini E, Sacchelli L, et al. Antiviral intrahepatic T-cell responses can be restored by blocking programmed death1 pathway in chronic hepatitis B. Gastroenterology. (2010) 138:682-93.e6814. doi: 10.1053/j.gastro.2009.09.052

11. Zhang Z, Zhang JY, Wherry EJ, Jin B, Xu B, Zou ZS, et al. Dynamic programmed death 1 expression by virus-specific $\mathrm{CD} 8 \mathrm{~T}$ cells correlates with the outcome of acute hepatitis B. Gastroenterology. (2008) 134:1938-49.e193133. doi: 10.1053 /j.gastro.2008.03.037

12. Boni C, Fisicaro P, Valdatta C, Amadei B, Di Vincenzo P, Giuberti T, et al. Characterization of hepatitis B virus (HBV)-specific T-cell dysfunction in chronic HBV infection. J Virol. (2007) 81:4215-25. doi: 10.1128/JVI.02844-06

13. Franklin C, Livingstone E, Roesch A, Schilling B, Schadendorf D. Immunotherapy in melanoma: recent advances and future directions. Eur J Surg Oncol. (2017) 43:604-11. doi: 10.1016/j.ejso.2016. 07.145

14. Liu J, Zhong Y, Peng S, Zhou X, Gan X. Efficacy and safety of PD1/PDL1 blockades versus docetaxel in patients with pretreated advanced non-smallcell lung cancer: a meta-analysis. Onco Targets Ther. (2018) 11:862332. doi: $10.2147 /$ OTT.S181413

15. Powles T, Eder JP, Fine GD, Braiteh FS, Loriot Y, Cruz C, et al. MPDL3280A (anti-PD-L1) treatment leads to clinical activity in metastatic bladder cancer. Nature. (2014) 515:558-62. doi: 10.1038/nature13904

16. Ansell SM, Lesokhin AM, Borrello I, Halwani A, Scott EC, Gutierrez M, et al. PD-1 blockade with nivolumab in relapsed or refractory hodgkin's lymphoma. N Engl J Med. (2015) 372:311-9. doi: 10.1056/NEJMoa1411087

17. Moskovitz J, Moy J, Ferris RL. Immunotherapy for head and neck squamous cell carcinoma. Curr Oncol Rep. (2018) 20:22. doi: 10.1007/s11912-018-0654-5

18. Crispe IN. Hepatic T cells and liver tolerance. Nat Rev Immunol. (2003) 3:51-62. doi: 10.1038/nri981

19. Karimi MH, Geramizadeh B, Malek-Hosseini SA. Tolerance induction in liver. Int J Organ Transplant Med. (2015) 6:45-54.

20. Tiegs G, Lohse AW. Immune tolerance: what is unique about the liver. $J$ Autoimmun. (2010) 34:1-6. doi: 10.1016/j.jaut.2009.08.008

21. Carambia A, Freund B, Schwinge D, Heine M, Laschtowitz A, Huber S, et al. TGF- $\beta$-dependent induction of $\mathrm{CD}^{+} \mathrm{CD} 25^{+}$ $\mathrm{Foxp}^{+}$tregs by liver sinusoidal endothelial cells. J Hepatol. (2014) 61:594-9. doi: 10.1016/j.jhep.2014.04.027

22. Makarova-Rusher OV, Medina-Echeverz J, Duffy AG, Greten TF. The yin and yang of evasion and immune activation in HCC. J Hepatol. (2015) 62:1420-9. doi: 10.1016/j.jhep.2015.02.038

23. Okusaka T, Ikeda M. Immunotherapy for hepatocellular carcinoma: current status and future perspectives. ESMO Open. (2018) 3:e000455. doi: 10.1136/esmoopen-2018-000455

24. Chen Y, Xu Y, Zhao M, Liu Y, Gong M, Xie C, et al. High-throughput $\mathrm{T}$ cell receptor sequencing reveals distinct repertoires between tumor and adjacent non-tumor tissues in HBV-associated HCC. Oncoimmunology. (2016) 5:e1219010. doi: 10.1080/2162402X.2016.1219010

25. Vandeven N, Nghiem P. Pathogen-driven cancers and emerging immune therapeutic strategies. Cancer Immunol Res. (2014) 2:9-14. doi: 10.1158/2326-6066.CIR-13-0179

26. Nakamoto N, Cho H, Shaked A, Olthoff K, Valiga ME, Kaminski $\mathrm{M}$, et al. Synergistic reversal of intrahepatic HCV-specific CD8 T cell exhaustion by combined PD-1/CTLA-4 blockade. PLoS Pathog. (2009) 5:e1000313. doi: 10.1371/journal.ppat.1000313

27. Li Z, Chen G, Cai Z, Dong X, Qiu L, Xu H, et al. Genomic and transcriptional profiling of tumor infiltrated $\mathrm{CD}^{+} \mathrm{T}$ cells revealed functional heterogeneity of antitumor immunity in hepatocellular carcinoma. Oncoimmunology. (2019) 8:e1538436. doi: 10.1080/2162402X.2018. 1538436

28. Webster GJ, Reignat S, Brown D, Ogg GS, Jones L, Seneviratne SL, et al. Longitudinal analysis of $\mathrm{CD}^{+} \mathrm{T}$ cells specific for structural and nonstructural hepatitis B virus proteins in patients with chronic hepatitis B: implications for immunotherapy. J Virol. (2004) 78:570719. doi: 10.1128/JVI.78.11.5707-5719.2004
29. Li H, Wu K, Tao K, Chen L, Zheng Q, Lu X, et al. Tim-3/galectin-9 signaling pathway mediates $\mathrm{T}$-cell dysfunction and predicts poor prognosis in patients with hepatitis B virus-associated hepatocellular carcinoma. Hepatology. (2012) 56:1342-51. doi: 10.1002/hep.25777

30. Li FJ, Zhang Y, Jin GX, Yao L, Wu DQ. Expression of LAG-3 is coincident with the impaired effector function of HBV-specific CD8(+) T cell in HCC patients. Immunol Lett. (2013) 150:116-22. doi: 10.1016/j.imlet.2012.12.004

31. Hsu PN, Yang TC, Kao JT, Cheng KS, Lee YJ, Wang YM, et al. Increased PD-1 and decreased CD28 expression in chronic hepatitis B patients with advanced hepatocellular carcinoma. Liver Int. (2010) 30:137986. doi: 10.1111/j.1478-3231.2010.02323.x

32. Gehring AJ, Ho ZZ, Tan AT, Aung MO, Lee KH, Tan KC, et al. Profile of tumor antigen-specific CD8 T cells in patients with hepatitis B virus-related hepatocellular carcinoma. Gastroenterology. (2009) 137:68290. doi: 10.1053 /j.gastro.2009.04.045

33. Trehanpati $\mathrm{N}$, Vyas AK. Immune regulation by $\mathrm{T}$ regulatory cells in hepatitis B virus-related inflammation and cancer. Scand J Immunol. (2017) 85:17581. doi: $10.1111 /$ sji. 12524

34. Sharma S, Khosla R, David P, Rastogi A, Vyas A, Singh D, et al. $\mathrm{CD} 4+\mathrm{CD} 25+\mathrm{CD} 127$ (low) regulatory $\mathrm{T}$ cells play predominant anti-tumor suppressive role in hepatitis B virus-associated hepatocellular carcinoma. Front Immunol. (2015) 6:49. doi: 10.3389/fimmu.2015.00049

35. Lim CJ, Lee YH, Pan L, Lai L, Chua C, Wasser M, et al. Multidimensional analyses reveal distinct immune microenvironment in hepatitis B virus-related hepatocellular carcinoma. Gut. (2018) 68:916-27. doi: 10.1136/gutjnl-2018-316510

36. Zhang HH, Mei MH, Fei R, Liu F, Wang JH, Liao WJ, et al. Regulatory $\mathrm{T}$ cells in chronic hepatitis $\mathrm{B}$ patients affect the immunopathogenesis of hepatocellular carcinoma by suppressing the anti-tumour immune responses. J Viral Hepat. (2010) 17:34-43. doi: 10.1111/j.1365-2893.2010. 01269.x

37. Lv Y, Cui M, Lv Z, Lu J, Zhang X, Zhao Z, et al. Expression and significance of peripheral myeloid-derived suppressor cells in chronic hepatitis B patients. Clin Res Hepatol Gastroenterol. (2018) 42:46269. doi: 10.1016/j.clinre.2018.04.002

38. Wang D, An G, Xie S, Yao Y, Feng G. The clinical and prognostic significance of CD14(+)HLA-DR(-/low) myeloid-derived suppressor cells in hepatocellular carcinoma patients receiving radiotherapy. Tumour Biol. (2016) 37:10427-33. doi: 10.1007/s13277-016-4916-2

39. Kondo Y, Shimosegawa T. Significant roles of regulatory $T$ cells and myeloid derived suppressor cells in hepatitis B virus persistent infection and hepatitis B virus-related HCCs. Int J Mol Sci. (2015) 16:330722. doi: $10.3390 /$ ijms 16023307

40. Huang A, Zhang B, Yan W, Wang B, Wei H, Zhang F, et al. Myeloidderived suppressor cells regulate immune response in patients with chronic hepatitis B virus infection through PD-1-induced IL-10. J Immunol. (2014) 193:5461-9. doi: 10.4049/jimmunol.1400849

41. Hoechst B, Voigtlaender T, Ormandy L, Gamrekelashvili J, Zhao F, Wedemeyer $\mathrm{H}$, et al. Myeloid derived suppressor cells inhibit natural killer cells in patients with hepatocellular carcinoma via the NKp30 receptor. Hepatology. (2009) 50:799-807. doi: 10.1002/hep.23054

42. Hoechst B, Ormandy LA, Ballmaier M, Lehner F, Kruger C, Manns MP, et al. A new population of myeloid-derived suppressor cells in hepatocellular carcinoma patients induces $\mathrm{CD} 4(+) \mathrm{CD} 25(+)$ Foxp3(+) T cells. Gastroenterology. (2008) 135:234-43. doi: 10.1053/j.gastro.2008.03.020

43. Kennedy PTF, Sandalova E, Jo J, Gill U, Ushiro-Lumb I, Tan AT, et al. Preserved T-cell function in children and young adults with immune-tolerant chronic hepatitis B. Gastroenterology. (2012) 143:63745. doi: 10.1053 /j.gastro.2012.06.009

44. Shi F, Shi M, Zeng Z, Qi RZ, Liu ZW, Zhang JY, et al. PD-1 and PD-L1 upregulation promotes CD8(+) T-cell apoptosis and postoperative recurrence in hepatocellular carcinoma patients. Int J Cancer. (2011) 128:88796. doi: $10.1002 /$ ijc. 25397

45. Tzeng HT, Tsai HF, Liao HJ, Lin YJ, Chen L, Chen PJ, et al. PD-1 blockage reverses immune dysfunction and hepatitis B viral persistence in a mouse animal model. PLoS ONE. (2012) 7:e39179. doi: 10.1371/journal.pone.0039179 
46. Arzumanyan A, Reis HM, Feitelson MA. Pathogenic mechanisms in HBVand HCV-associated hepatocellular carcinoma. Nat Rev Cancer. (2013) 13:123-35. doi: 10.1038/nrc3449

47. Messerini L, Novelli L, Comin CE. Microvessel density and clinicopathological characteristics in hepatitis $\mathrm{C}$ virus and hepatitis B virus related hepatocellular carcinoma. J Clin Pathol. (2004) 57:867-71. doi: 10.1136/jcp.2003.015784

48. Mazzanti R, Messerini L, Monsacchi L, Buzzelli G, Zignego AL, Foschi M, et al. Chronic viral hepatitis induced by hepatitis $\mathrm{C}$ but not hepatitis B virus infection correlates with increased liver angiogenesis. Hepatology. (1997) 25:229-34. doi: 10.1002/hep.510250142

49. Hsiao YW, Chiu LT, Chen CH, Shih WL, Lu TP. Tumor-infiltrating leukocyte composition and prognostic power in hepatitis B- and hepatitis C-related hepatocellular carcinomas. Genes. (2019) 10:630. doi: 10.3390/genes10080630

50. Hetta HF, Zahran AM, Mansor SG, Abdel-Malek MO, Mekky MA, Abbas WA. Frequency and implications of myeloid-derived suppressor cells and lymphocyte subsets in Egyptian patients with hepatitis C virus-related hepatocellular carcinoma. J Med Virol. (2019) 91:131928. doi: 10.1002/jmv.25428

51. Yoshizawa K, Abe H, Kubo Y, Kitahara T, Aizawa R, Matsuoka M, et al. Expansion of CD4(+)CD25(+)FoxP3(+) regulatory $\mathrm{T}$ cells in hepatitis $\mathrm{C}$ virus-related chronic hepatitis, cirrhosis and hepatocellular carcinoma. Hepatol Res. (2010) 40:179-87. doi: 10.1111/j.1872-034X.2009.00587.x

52. Kitahara M, Mizukoshi E, Nakamoto Y, Mukaida N, Matsushima K, Kaneko S. Efficient generation of highly immunocompetent dendritic cells from peripheral blood of patients with hepatitis C virus-related hepatocellular carcinoma. Int Immunopharmacol. (2014) 21:346-53. doi: 10.1016/j.intimp.2014.05.023

53. Shiraki T, Takayama E, Magari H, Nakata T, Maekita T, Enomoto S, et al. Altered cytokine levels and increased CD4+CD57+ T cells in the peripheral blood of hepatitis C virus-related hepatocellular carcinoma patients. Oncol Rep. (2011) 26:201-8. doi: 10.3892/or.2011.1258

54. Yang R, Gao N, Chang Q, Meng X, Wang W. The role of IDO, IL-10, and TGF$\beta$ in the HCV-associated chronic hepatitis, liver cirrhosis, and hepatocellular carcinoma. J Med Virol. (2019) 91:265-71. doi: 10.1002/jmv.25083

55. Perrella O, Cuomo O, Sbreglia C, Monaco A, Gnarini MR, Gentile B, et al. IL18 and interferon-gamma in HCV-related hepatocellular carcinoma: a model of interplay between immune status and cancer. J Biol Regul Homeost Agents. (2009) 23:251-8.

56. Yau T, Park J, Finn R, Cheng AL, Mathurin P, Edeline J, et al. CheckMate 459: a randomized, multi-center phase 3 study of nivolumab vs sorafenib as first-line treatment in patients with advanced hepatocellular carcinoma. Ann Oncol. (2019) 30(Suppl. 5):v874-5. doi: 10.1093/annonc/mdz 394.029

57. El-Khoueiry AB, Sangro B, Yau T, Crocenzi TS, Kudo M, Hsu $\mathrm{C}$, et al. Nivolumab in patients with advanced hepatocellular carcinoma (CheckMate 040): an open-label, non-comparative, phase $1 / 2$ dose escalation and expansion trial. Lancet. (2017) 389:2492-502. doi: 10.1016/S0140-6736(17)31046-2

58. Yoon SE, Hur JY, Lee KK, Lee SJ, Lee J, Paik SW, et al. Real-world data on nivolumab treatment in Asian patients with advanced hepatocellular carcinoma. Ann Oncol. (2018) 29:viii205-70. doi: 10.1093/annonc/mdy 282.082

59. Finkelmeier F, Czauderna C, Perkhofer L, Ettrich TJ, Trojan J, Weinmann A, et al. Feasibility and safety of nivolumab in advanced hepatocellular carcinoma: real-life experience from three German centers. J Cancer Res Clin Oncol. (2019) 145:253-9. doi: 10.1007/s00432-0182780-8

60. Zhu AX, Finn RS, Edeline J, Cattan S, Ogasawara S, Palmer D, et al. Pembrolizumab in patients with advanced hepatocellular carcinoma previously treated with sorafenib (KEYNOTE-224): a non-randomised, open-label phase 2 trial. Lancet Oncol. (2018) 19:940-52. doi: 10.1016/S1470-2045(18) 30351-6

61. Finn R, Ryoo BY, Merle P, Kudo M, Bouattour M, Lim HY, et al. O027Pembrolizumab (Pembro) therapy vs best supportive care (BSC) in advanced hepatocellular carcinoma (HCC): KEYNOTE-240. Ann Oncol. (2019) 30:iv135-iv136. doi: 10.1093/annonc/mdz154.026
62. Pishvaian JM, J Weiss G, Steven Falchook G, S Yee N, Gil Martin M, Shahda S, et al. 1151P Cemiplimab, a human monoclonal anti-PD1 , in patients (pts) with advanced or metastatic hepatocellular carcinoma (HCC): data from an expansion cohort in a phase I study. (2018) 29:viii410. doi: 10.1093/annonc/mdy288.024

63. Yen C-J, Markman B, Chao Y, Hill A, Kang J, Wang L, et al. P-140Preliminary results of a phase $1 \mathrm{~A} / 1 \mathrm{~B}$ study of BGB-A317, an anti-PD-1 monoclonal antibody (mAb), in patients with advanced hepatocellular carcinoma (HCC). Ann Oncol. (2017) 28:iii54(Suppl. 3). doi: 10.1093/annonc/mdx261.139

64. Qin S, Ren Z, Meng Z, Chen Z, Chai X, Xiong J, et al. Camrelizumab in patients with previously treated advanced hepatocellular carcinoma: a multicentre, open-label, parallel-group, randomised, phase 2 trial. Lancet Oncol. (2020) 21:571-80. doi: 10.1016/S1470-2045(20)30011-5

65. Wainberg ZA, Segal NH, Jaeger D, Lee K-H, Marshall J, Antonia SJ, et al. Safety and clinical activity of durvalumab monotherapy in patients with hepatocellular carcinoma (HCC). J Clin Oncol. (2017) 35:4071. doi: 10.1200/JCO.2017.35.15_suppl.4071

66. Kelley RK, Abou-Alfa GK, Bendell JC, Kim T-Y, Borad MJ, Yong W-P, et al. Phase I/II study of durvalumab and tremelimumab in patients with unresectable hepatocellular carcinoma (HCC): phase I safety and efficacy analyses. J Clin Oncol. (2017) 35(Suppl. 15):4073. doi: 10.1200/JCO.2017.35.15_suppl.4073

67. Floudas CS, Xie C, Brar G, Morelli MP, Fioravanti S, Walker M, et al. Combined immune checkpoint inhibition (ICI) with tremelimumab and durvalumab in patients with advanced hepatocellular carcinoma (HCC) or biliary tract carcinomas (BTC). J Clin Oncol. (2019) 37:336. doi: 10.1200/JCO.2019.37.4_suppl.336

68. He A, Yau T, Hsu C, Kang Y-K, Kim T-Y, Santoro A, et al. Nivolumab (NIVO) + ipilimumab (IPI) combination therapy in patients (pts) with advanced hepatocellular carcinoma (aHCC): subgroup analyses from CheckMate 040. J Clin Oncol. (2020) 38:512. doi: 10.1200/JCO.2020.38.4_suppl.512

69. Pishvaian MJ, Lee MS, Ryoo B-Y, Stein S, Lee K-H, Liu B, et al. Phase Ib Study of atezolizumab + bevacizumab in HCC- updated safety and clinical activity. In: Presentation Presented at: European Society for Medical Oncology (ESMO) Congress 2018. October 19-23. Munich (2018).

70. Cheng AL, Qin S, Ikeda M, Galle P, Ducreux M, Zhu A, et al. Atezolizumab + bevacizumab vs sorafenib in patients with unresectable hepatocellular carcinoma: phase 3 results from IMbrave150. In: Presentation Presented at: European Society for Medical Oncology (ESMO) ASIA Congress 2019. November 22-24. Singapore: Republic of Singapore (2019).

71. Ikeda M, Sung MW, Kudo M, Kobayashi M, Baron AD, Finn RS, et al. A phase $1 \mathrm{~b}$ trial of lenvatinib (LEN) plus pembrolizumab (PEM) in patients (pts) with unresectable hepatocellular carcinoma (uHCC). Ann Oncol. (2019) 30(Suppl. 5):v253-324. doi: 10.1200/JCO.2018.36.15_suppl.4076

72. Xu J, Zhang Y, Jia R, Yue C, Chang L, Liu R, et al. Anti-PD-1 antibody SHR-1210 combined with apatinib for advanced hepatocellular carcinoma, gastric, or esophagogastric junction cancer: an open-label, dose escalation and expansion study. Clin Cancer Res. (2019) 25:51523. doi: 10.1158/1078-0432.CCR-18-2484

73. Mamdani H, Wu H, O'Neil BH, Sehdev A. Excellent response to anti-PD-1 therapy in a patient with hepatocellular carcinoma: case report and review of literature. Discov Med. (2017) 23:331-6.

74. Kudo M, Lim H, Cheng A-L, Chao Y, Yau T, Ogasawara S, et al. Phase III study of pembrolizumab (pembro) versus best supportive care (BSC) for second-line therapy in advanced hepatocellular carcinoma (aHCC): KEYNOTE-240 Asian subgroup. J Clin Oncol. (2020) 38:526. doi: 10.1200/JCO.2020.38.4_suppl.526

75. Hato T, Zhu AX, Duda DG. Rationally combining anti-VEGF therapy with checkpoint inhibitors in hepatocellular carcinoma. Immunotherapy. (2016) 8:299-313. doi: 10.2217/imt.15.126

76. Sherman AC, Trehanpati N, Daucher M, Davey RT, Masur H, Sarin SK, et al. Augmentation of hepatitis B virus-specific cellular immunity with programmed death receptor-1/programmed death receptor-L1 blockade in hepatitis B virus and HIV/hepatitis B virus coinfected patients treated with adefovir. AIDS Res Hum Retroviruses. (2013) 29:66572. doi: 10.1089/aid.2012.0320

77. Balsitis S, Gali V, Mason PJ, Chaniewski S, Levine SM, Wichroski MJ, et al. Safety and efficacy of anti-PD-L1 therapy in the woodchuck model of HBV infection. PLoS ONE. (2018) 13:e0190058. doi: 10.1371/journal.pone.0190058 
78. Gane E, Verdon DJ, Brooks AE, Gaggar A, Nguyen AH, Subramanian GM, et al. Anti-PD-1 blockade with nivolumab with and without therapeutic vaccination for virally suppressed chronic hepatitis B: a pilot study. J Hepatol. (2019) 71:900-7. doi: 10.1016/j.jhep.2019.06.028

79. Ohaegbulam KC, Assal A, Lazar-Molnar E, Yao Y, Zang X. Human cancer immunotherapy with antibodies to the PD-1 and PD-L1 pathway. Trends $\mathrm{Mol}$ Med. (2015) 21:24-33. doi: 10.1016/j.molmed.2014.10.009

80. Dai X, Xue J, Hu J, Yang SL, Chen GG, Lai PBS, et al. Positive expression of programmed death ligand 1 in peritumoral liver tissue is associated with poor survival after curative resection of hepatocellular carcinoma. Transl Oncol. (2017) 10:511-7. doi: 10.1016/j.tranon.2017.03.009

81. Gu X, Gao XS, Xiong W, Guo W, Han L, Bai Y, et al. Increased programmed death ligand-1 expression predicts poor prognosis in hepatocellular carcinoma patients. Onco Targets Ther. (2016) 9:4805-13. doi: 10.2147/OTT.S110713

82. Finkelmeier F, Canli O, Tal A, Pleli T, Trojan J, Schmidt M, et al. High levels of the soluble programmed death-ligand (sPD-L1) identify hepatocellular carcinoma patients with a poor prognosis. Eur J Cancer. (2016) 59:1529. doi: 10.1016/j.ejca.2016.03.002

83. Gao Q, Wang XY, Qiu SJ, Yamato I, Sho M, Nakajima Y, et al. Overexpression of PD-L1 significantly associates with tumor aggressiveness and postoperative recurrence in human hepatocellular carcinoma. Clin Cancer Res. (2009) 15:971-9. doi: 10.1158/1078-0432.CCR-08-1608

84. Han X, Gu YK, Li SL, Chen H, Chen MS, Cai QQ, et al. Pre-treatment serum levels of soluble programmed cell death-ligand 1 predict prognosis in patients with hepatitis B-related hepatocellular carcinoma. J Cancer Res Clin Oncol. (2019) 145:303-12. doi: 10.1007/s00432-018-2758-6

85. Zeng Z, Shi F, Zhou L, Zhang MN, Chen Y, Chang XJ, et al. Upregulation of circulating $\mathrm{PD}-\mathrm{L} 1 / \mathrm{PD}-1$ is associated with poor post-cryoablation prognosis in patients with HBV-related hepatocellular carcinoma. PLoS ONE. (2011) 6:e23621. doi: 10.1371/journal.pone.0023621

86. Zhang L, Wang Q, Zhao P, Hu X, Jiang Y. Effects of entecavir on peripheral blood lymphocyte profiles in chronic hepatitis B patients with suboptimal responses to adefovir. Clin Exp Pharmacol Physiol. (2014) 41:51423. doi: 10.1111/1440-1681.12245

87. Bell CC, Faulkner L, Martinsson K, Farrell J, Alfirevic A, Tugwood J, et al. T-cells from HLA-B*57:01+ human subjects are activated with abacavir through two independent pathways and induce cell death by multiple mechanisms. Chem Res Toxicol. (2013) 26:759-66. doi: 10.1021/ tx400060p

88. Li Z, Li N, Li F, Zhou Z, Sang J, Chen Y, et al. Immune checkpoint proteins PD1 and TIM-3 are both highly expressed in liver tissues and correlate with their gene polymorphisms in patients with HBV-related hepatocellular carcinoma. Medicine. (2016) 95:e5749. doi: 10.1097/MD.0000000000005749

89. Zhang G, Li N, Zhang P, Li F, Yang C, Zhu Q, et al. PD-1 mRNA expression is associated with clinical and viral profile and PD1 3'-untranslated region polymorphism in patients with chronic HBV infection. Immunol Lett. (2014) 162:212-6. doi: 10.1016/j.imlet.2014.09.001

90. Kah J, Koh S, Volz T, Ceccarello E, Allweiss L, Lutgehetmann $\mathrm{M}$, et al. Lymphocytes transiently expressing virus-specific $\mathrm{T}$ cell receptors reduce hepatitis B virus infection. J Clin Invest. (2017) 127:3177-88. doi: 10.1172/JCI93024

91. Tan AT, Yang N, Lee Krishnamoorthy T, Oei V, Chua A, Zhao X, et al. Use of expression profiles of HBV-DNA integrated into genomes of hepatocellular carcinoma cells to select T cells for immunotherapy. Gastroenterology. (2019) 156:1862-76.e1869. doi: 10.1053/j.gastro.2019.01.251

92. Nishijima TF, Shachar SS, Nyrop KA, Muss HB. Safety and tolerability of PD-1/PD-L1 inhibitors compared with chemotherapy in patients with advanced cancer: a meta-analysis. Oncologist. (2017) 22:470-9. doi: 10.1634/theoncologist.2016-0419

93. Postow MA. Managing immune checkpoint-blocking antibody side effects. Am Soc Clin Oncol Educ Book. (2015) 7683. doi: 10.14694/EdBook_AM.2015.35.76

94. Kim KW, Ramaiya NH, Krajewski KM, Jagannathan JP, Tirumani $\mathrm{SH}$, Srivastava A, et al. Ipilimumab associated hepatitis: imaging and clinicopathologic findings. Invest New Drugs. (2013) 31:10717. doi: 10.1007/s10637-013-9939-6

95. Zhang X, Zhou Y, Chen C, Fang W, Cai X, Zhang X, et al. Hepatitis $B$ virus reactivation in cancer patients with positive Hepatitis B surface antigen undergoing PD-1 inhibition. J Immunother Cancer. (2019) 7:322. doi: 10.1186/s40425-019-0808-5

96. Seeger C, Mason WS. Molecular biology of hepatitis B virus infection. Virology. (2015) 479-480:672-86. doi: 10.1016/j.virol.2015.02.031

97. Chen Y, Tian Z. HBV-induced immune imbalance in the development of HCC. Front Immunol. (2019) 10:2048. doi: 10.3389/fimmu.2019.02048

98. Levrero M, Zucman-Rossi J. Mechanisms of HBV-induced hepatocellular carcinoma. J Hepatol. (2016) 64:S84-101. doi: 10.1016/j.jhep.2016.02.021

99. Patel SP, Kurzrock R. PD-L1 expression as a predictive biomarker in cancer immunotherapy. Mol Cancer Ther. (2015) 14:84756. doi: 10.1158/1535-7163.MCT-14-0983

Conflict of Interest: The authors declare that the research was conducted in the absence of any commercial or financial relationships that could be construed as a potential conflict of interest.

Copyright (c) $2020 \mathrm{Li}$, Yan, Zhu, Chen, Fu, Zhang, Tong, Liu, Zheng, Zhao, Jiang and Fang. This is an open-access article distributed under the terms of the Creative Commons Attribution License (CC BY). The use, distribution or reproduction in other forums is permitted, provided the original author(s) and the copyright owner(s) are credited and that the original publication in this journal is cited, in accordance with accepted academic practice. No use, distribution or reproduction is permitted which does not comply with these terms. 